\title{
The Indian Protective Service Accused: The Logic of Defamation in the Dispute for the Control of Indigenous Territories in the State of Amazonas, 1931
}

\author{
Ana Flávia Moreira Santos? \\ 'Programa de Pós-Graduação em Antropologia, Universidade Federal de Minas Gerais, \\ Belo Horizonte/MG, Brasil
}

\begin{abstract}
The present article analyzes the Inquiry into the Indian Inspectorate in Amazonas and Acre, established in 1931 by order of the Federal Intervenor of the Amazonas. Taking as our approach an analysis of regional contexts, we link the inquiry to land conflicts that occurred in the previous decade, which gravitated around the imposition of a commercial monopoly on a resource historically configured as a "remedy for poverty" - Brazil nut trees. We demonstrate how narratives regarding these conflicts were triggered in the inquiry according to a logic that aimed to criminalize indigenous peoples and Indian Protective Service representatives as a way of accumulating legitimacy for the extralegal exercise of power. Finally, we illuminate the symbolic character of these disputes, which sought to restrict the legal meanings of "Indian" in order to question the legitimacy of the Indian Service in its administration of the so-called "semi-civilized peoples" and to restrict indigenous peoples' access to State resources.
\end{abstract}

Keywords: Territorial conflicts; Indian Protection Service; History of Amazonas; Mura; Munduruku; Symbolic Power. 


\section{O Serviço de Proteção aos Índios no banco dos réus: a lógica da detratação na disputa pelo controle de territórios e indígenas no Estado do Amazonas, 1931}

\section{Resumo}

O presente artigo analisa o Inquérito na Inspetoria dos Índios no Amazonas e Acre, instaurado em 1931 por ordem do Interventor Federal no Amazonas. Em uma aproximação a contextos locais e regionais, articula o inquérito aos conflitos fundiários ocorridos na década anterior, em torno da imposição do monopólio comercial sobre um recurso que se configurava, historicamente, como o "remédio da pobreza" - os castanhais. $O$ artigo demonstra como as narrativas acerca desses conflitos são acionadas, no inquérito, segundo a lógica circular da detratação, visando a criminalização de indígenas e representantes do SPI, como forma de acumular legitimidade para o exercício extralegal do poder. Por fim, ilumina o caráter propriamente simbólico das disputas, que buscavam restringir os sentidos legais da categoria "índio", retirando a legitimidade da Inspetoria na atuação entre os chamados "semicivilizados", e alijando os indígenas de canais de acesso ao Estado.

Palavras-Chave: Conflitos territoriais; Serviço de Proteção aos índios; História do Amazonas; Mura; Munduruku; Poder Simbólico. 


\section{El Servicio de Protección al Indio en el banquillo de los acusados: la lógica de la difamación en la disputa por el control de los territorios y los pueblos indígenas en el Estado de Amazonas, 1931}

\section{Resumen}

Este artículo analiza la Investigación de la Inspección de Indios en Amazonas y Acre, iniciada en 1931 por orden del Interventor Federal en Amazonas. En una aproximación a los contextos locales y regionales, articula la investigación a los conflictos territoriales ocurridos en la década anterior, en torno a la imposición del monopolio comercial sobre un recurso que históricamente se configuró como el "remedio de la pobreza": las castañas. El artículo demuestra cómo, en la Investigación, se desencadenan las narrativas sobre estos conflictos según la lógica circular de la difamación, apuntando a la criminalización de los representantes indígenas y del SPI, como una forma de acumular legitimidad para el ejercicio extralegal del poder. Ilumina el carácter propiamente simbólico de las disputas, que buscaban restringir los significados jurídicos de la categoría “indígena”, quitando la legitimidad del SPI en la administración de los llamados "semi-civilizados", y removiendo a los indígenas de los canales de acceso al Estado.

Palabras clave: Conflictos territoriales; Servicio de Protección Indígena; Historia de Amazonas; Mura; Munduruku; Poder simbólico. 


\title{
The Indian Protective Service Accused: The Logic of Defamation in the Dispute for the Control of Indigenous Territories in the State of Amazonas, 1931
}

\author{
Ana Flávia Moreira Santos
}

\section{Introduction}

The Inspectorate, according to its procedures, has created "a State within the State", in which it is the absolute authority, dividing up [at] its discretion the municipalities into lots, which it delivers to the administration of its agents. With this protocol, as we have said, it has created an asphyxiating atmosphere inside [its territories] for those who, in defense of their rights and interests, try to peacefully resist it. Old landholders with property titles find themselves stripped of what they have maintained as their patrimony for many years. (BRASIL 1931 Vol. I: 42/43)

If we swap out some terms -such as "lots" for "indigenous lands" - the above paragraph would not seem strange to any Brazilian reader in the 21st century. Someone with a good memory would think that they might have been from a news story published at the beginning of the present decade in a major magazine, or perhaps from an affirmation made during the most recent Parliamentary Inquiry Commission into FUNAI and INCRA ${ }^{1}$. This, however, is a passage taken from documents that long predate Brazilian Constitution of 1988, which instituted new parameters for the recognition of indigenous territories. The paragraph comes from the final report of the Inquiry into the Inspectorate of Indians Protection Service in Amazonas and Acre, produced by a commission established in January 1931 by the Federal Intervenor in the State of Amazonas, Álvaro Maia.

What motivated the establishment of this raping of Indigenous lands during a historical period in which the demarcation of Indigenous lands was not yet an objective of the indigenous policy? Why these accusations against an agency whose performance, (considering the dimensions of the territories and indigenous populations in Amazonas and Acre), could at best be described as "incipient"?

The inquiry into the SPI's Inspectorate was not, in and of itself, an exceptional fact at the dawn of the New Republic in Brazil. The establishment of investigations to examine the actions of directors and employees of state and federal administrative bodies was part of the new regime's general practice, which sought to purge the evils incarnated in agencies and individuals likely to be associated with the defeated old Republic. The denunciations in public spaces and the press were part of an ideological language that sought to impose the "new". This language often expressed disputes between political groups for prestige and space in the situation that was then consolidating itself in early $20^{\text {th }}$ Century Brazil (SANTOS 2009).

\footnotetext{
1 This is the article entitled "A farra da antropologia oportunista", published by Revista Veja in June of 2012010 , which accuses anthropologists of "inventing" indigenous groups and quilombolas and of promoting "a true demarcation industry" (COUTINHO, PAULIN, MEDEIROS 2010). Five years later, a Congressional Investigation Committee (Comissão Parlamentar de Inquérito - a CPI da FUNAI e do INCRA) would be established to investigate the routines and administrative practices adopted by the Fundação Nacional do Índio (FUNAI) and by the Instituto de Regularização e Reforma Agrária in respectively demarcating indigenous and quilombola lands. Proposed and sustained by members of the so-called Agrobusiness Parlimentary Front (FPA), the CPI ran between 2015 and 2017 and reccomended the indictment of 67 people, including community leaders, anthropologists, and civil servants (AGÊNCIA BRASIL, 2017). See COSTA 2019.
} 
We also know, on the other hand, that the administrative reforms that followed the so-called Revolution of 1930 resulted in a severe crisis for Brazil's Indian Protection Service, which lost administrative autonomy and saw the dismantling of its network of local action units, the indigenous posts (SOUZA LIMA 1995). ${ }^{2}$ The inquiry should not be read, however, as a mere reflection of this general picture, sometimes understood as a direct consequence of General Rondon's refusal to participate in the revolutionary movement that took control of the Brazilian State. As noted by Souza Lima (1995), the relations between Rondon's collaborators and the sectors that were being established in the government were extraordinarily complex. In the case of Amazonas, advisors close to the Inspectorate maintained alliances with political forces that were aligned with the Revolution, even assuming positions in the Intervening Body during the period in which the inquiry commission was operating. ${ }^{3}$

In the present article, we try to demonstrate how specific historical local and regional contexts can illuminate inquiry into broader events, explaining interests and movements through which sectors of regional oligarchies imposed, through political negotiation, the dismantling of the Indian Inspectorate and the subsequent rape of Indigenous lands. I discuss the inquiry through which they did this as a device for the production of interested truths (BOURDIEU 1989) - hierarchical, authorized truths that are capable of enhancing, on the ground, the arbitrary and violent exercise of physical force. From this perspective, the criminal expressions under which territorial conflicts are registered (ZHOURI, LASCHEFSKI 2010) can be seen as a dimension of a deeper struggle -- a symbolic, classificatory struggle, in which the most serious threats are created by the mere possibility that indigenous peoples might access administrative channels authorized to define the physical and symbolic realities (BOURDIEU 1989) which give legal access to rights. By analyzing the inquiry and the struggles that surrounded it in this way, we argue for a better understanding of the lasting effects of the rearrangement of political forces, such as the reorganization of apparatuses and devices for training and controlling the workforce that resulted in the collapse of the Indian Protection Service in the $1930 s$.

\section{The Inquiry}

Despite the existence of a single final report regarding the inquiry, the records of it are a very heterogeneous ${ }^{4}$ set of papers resulting from a series of independent and parallel investigations. Part of the survey was administrative in nature, focusing on financial resource flows and the management of public assets (allocation of funds; indigenous assets; use and conservation of river vessels; administration of the São Marcos National Farm). Another part was the receipt of complaints presented by people who thought they had been harmed by the Inspectorate or who had witnessed arbitrary acts committed by its representatives.

\footnotetext{
2 As Souza Lima shows (1995), from 1930 on the SPI became part of the Ministry of Labor, Industry and Commerce (MTIC) but it had no administrative autonomy as part of the Department of Settlement. After 1934, it was shifted to the War Ministry. According to Souza Lima, between 1930 and 19, the total number of the Inspectorate's units fell from 67 to less than 20 across the nation. In the jurisdiction of the Amazonas and Acre Inspectorate, the fall of the number of Service units seems to have been less dramatic, but analyses demonstrate the total failure of the SPI's ability to intervene in the region during the 1930 and the beginning of the " 40 (MELO 2007).

3 Although fragmentary, the data shows a political group containing a significant presence of sectors of the Army, which, to some extent, contemplated in the reformulation of the state's bureaucracy, sought to oppose the old oligarchies and which gained space in this process. It is possible to identify by name two people close to the Indian Protection Service with clear links to the tententista movement and the 193o Revolution: Lieutenant Colonel Aluísio Ferreira, who was part of the group of lieutenants that took power in Amazonas in 1924 and was invited by Rondon to take over as deputy chief of the Santo Antônio do Rio Madeira Telegraph Post at the end of the 1920s; and law student Francisco Pereira da Silva, an important collaborator of the Inspectorate in 1927 and 1928, summoned to participate in the State Government Board in October 1930, and, after its dissolution, appointed Secretary General of the State Government, a position he held until 1932 (SANTOS, 2009).

4 The document set consists of seven volumes, which contain the commission's final report and the records of the inquiries themselves (vol. I); official letters and opinions produced by the Commission, or documents received by it (offices, reports, letters, invoices) (vol. II); defense allegations, including documentary annexes (vol. III); a set of photographs presented with the defense allegations (vol. IV); records of the inquiry carried out in São Gabriel da Cachoeira (vol. V). Available for public consultation, they are all part of the Fundo “Tribunal Especial”, Série "Procuradoria”, of the Brazilian National Archives Collection, where they can be located as Notation \#640, Volumes 1 to 5, Deposit 311.
} 
The reports were in sent writing to (or given in person in) the Rio Negro Palace room reserved for the Commission of Inquiry's work. Once registered, the accusations resulted into smaller sub-inquiries, with the summoning of witnesses and requests for information from various agents such as merchants and local authorities (judges, notary publics, police delegates and sub-delegates).

Another procedure adopted by the Inquiry was the formulation of questions about the actions of the Inspectorate among the populations it administered. A questionnaire containing six questions was sent to mayors and judges through official letters in which the Federal Intervenor requested the opening of "rigorous local inquiries" in order to verify the following:

(a) Do Tribes, Hordes, or Villages of true forest-dwellers in fact exist, as defined by the terms of the Civil Code;

(b) Where are they located;

(c) Are there groups regularly constituted and installed by the Indian Inspectorate;

(d) What is their situation;

(e) Do those in charge of the Indigenous Posts limit their activities to those laid out under their mandate, or do they take advantage of nut harvests to buy and sell nuts;

(f) Do those in charge of the Indigenous Posts stay in the areas under their responsibility or do they widen their activities over other lands (BRASIL 1931: Vol. I, fl. 212).

The questions are indicative of some of the survey's main interests. These concerned access to certain territories, which placed the land issue at the heart of the inquiry. In the vast territorial expanse of the Amazon, landholdings have historically constituted islands characterized by the occurrence of commercially valuable resources and by the presence of labor that can be fixed in place to work these. The rubber plantation ${ }^{5}$ is the most classic form of this model (PACHECO DE OLIVEIRA 1979). In 1931, these resources were mainly nut groves and circuits, especially those along navigable rivers, already benefiting from the presence of so-called semicivilized indigenous peoples. The Inquiry was questioning the principles upon which the Inspectorate argued for its the prerogatives in managing lands containing Brazil nut trees and in the administration of indigenous people and the commercialization of Brazil nuts. "Catechizing Brazil nut grove workers in order to discover Indians" is the phrase employed that best sums up the core of the denunciations reported to the Commission of Inquiry against the Inspectorate (BRASIL 1931 Vol. I: 73v).

\section{The decline of the rubber economy and "nut fever"}

Readers must bear in mind that in 1910, the Amazon produced more than $50 \%$ of the rubber consumed in the world (reaching 61\% in 1892). However, by the 1920s, the English and Dutch colonies in Asia were producing $90 \%$ of the world's rubber (SOARES 1927). The marginalization of the Amazon vis-à-vis the international rubber trade was abrupt and definitive; its effects were drastic. A dizzying reduction in state revenues (largely based on export taxes) took place. Rubber traders underwent abrupt decapitalization and insolvency, and this effected the entire rubber extraction and commercialization system. There was a complete depreciation of assets involved in the credit network, including the rubber plantations and circuits themselves. Long-distance river transport systems broke down. Imports collapsed, especially those of companies dedicated to supplying of luxury items or trade goods to rubber traders (SANTOS, R. 1980; WEINSTEIN 1993). Amid the economic depression, massive population rearrangements took place. Rubber tappers abandoned their circuits and retreated to capital cities,

5 Translator's Note: many resources in the Amazon (notoriously rubber) do not occur in concentrated form but are spread out throughout a given region. The harvesting paths that link these resources are referred to as "circuits". In the present text, we use both "groves" "plantations" and "circuits" interchangeably to refer to collections of nut-bearing plants harvested by local workers. 
regional centers and villages, to other parts of the Amazon, or to other states entirely. Scarcity, famine, and epidemics created precarious living conditions for those who gathered in the region's cities, a framework that would be further aggravated by the outbreak of the First World War in 1914 (REIS 1944).

Although abrupt, the collapse of the Amazonian rubber economy did not entirely extinguish rubber extraction and trading activities in the region, nor did it immediately remove them from the center of political and economic life in Amazonas (WEINSTEIN 1993). It created important changes in the spheres directly related to production and to the initial stages of commercialization, however. Over the course of the decade, these changes were reflected in new conditions for those who remained engaged in the extraction of goods from the jungle. The inability of traders and rubber tappers to continue to supply rubber plantations with all the necessary items for their operation caused a significant sea-change in the mechanisms of controlling labor and extracting surpluses. Activities aimed at the self-sustainability of rubber tappers that had previously been prohibited and harshly repressed, - subsistence farming, hunting, fishing — became a basic condition for extractive production in the region (REIS 1953; WEINSTEIN 1993). In Amazonas during the Alcântara Bacelar administration (1917 - 1920), the SPI Inspectorate had been directly involved in government efforts to produce food, control population flows, create infrastructure, and order territories, among other forms of subsidiary activities to extractive enterprise. ${ }^{6}$

Diversification of production and exportation was another fundamental strategy for the survival of extractive enterprise in the Amazon. Products such as nuts, balata, pirarucu, guaraná, and wood took on greater relative importance in the regional economy, contributing to diluting the risks of the extractive enterprise. The Brazil nut, in particular, prevented the hinterland from becoming completely abandoned according to Reis (1944). Some characteristics of this product must be highlighted, particularly its historical relationship with the so-called "rubber economy".

The rubber tree is a plant of the floodplains and river margins. Rubber extraction is carried out in the summer (BRASIL 1929). Brazil nuts, characteristic of the higher interfluvial uplands, are harvested during the winter rainy season. This facilitates access and production transport. The complementarity of these two products in terms of their seasonality meant that Brazil nut production remained high even during the rubber boom, and was even more easily associated with rubber production after the bust. But while the rubber circuits ended up being the regional model of land ownership, the huge difference between the value of the two products meant that nut circuits remained areas of public domain and free extraction. They were thus historically known as the "remedy for poverty". 7 In the state of Pará, as indicated by Emmi (1987), this situation gave nut workers a certain autonomy in relation to commercial capital: they even benefited from competition between agents of private capital.

The value correlation between rubber and Brazil nuts changed during the 1920s. With the end of World War I (1914-1918) and the normalization of trade with Europe, there was an increase in demand for Brazil nuts on the international market. The highest prices were registered between 1920 and 1925 (BRAZIL 1929). In 1922, rubber was at its lowest price since 1910. In 1923 and 1924, rubber prices would have a brief and artificial recovery, in response to the U.K.'s pricing policies in the face of overproduction in British rubber colonies (SOARES 1927).

6 Alcântara Bacelar adopted a discourse of searching for "new props" for the Amazonian economy, placing at the center of the government's programs the rationalizing and modernizing of "archaic" Amazonian agriculture through the dissemination of education. The civilizing character of this project is evident. The Inspectorate of the Service for the Protection of Indians came to occupy the place of a preferred partner in it. I have tried to demonstrate elsewhere how, in addition to an ideological identity between developmental goals and the fraternal protection of Native populations, an alignment of interests was created between regional oligarchies and sectors of the Federal Government, resulting in a joint effort to implement a plan for economic recovery based on the recruitment of indigenous labor for different purposes (SANTOS 2009; 2014).

7 In the case of Amazonas, this process seems to have undergone oscillations, even though its meaning is the same from the 1920 onwards. At the beginning of the 2oth century, Governor Silvério Nery deplored the maintenance of Brazil nut groves as public lands for free extraction, as established in Law no. 231 of 10/09/1898. He requested that the Amazon Congress modify this law, claiming that it was impossible for the State to monitor compliance (AMAZONAS 1920: 57). 
The impact of this process was soon felt on the lands occupied by indigenous peoples. Invasions of indigenous territories, threats towards or the effective domination of indigenous peoples, forcing them to slave labor, occurred, throughout the period of the decline in rubber's fortunes. This was true even during the Alcântara Bacelar Government, which was characterized by a certain alignment of interests between regional oligarchies and sectors of the Federal Government (SANTOS 2009). In the late 1910s, however, documents such as the Indian Inspectorate's annual reports not only show tensions and fissures in this alignment, but also a resurgence of conflicts. These began to draw a new geography in the Amazon, which was based on Brazil nut circuits that were known for their abundant production (BRASIL 1929), especially in the Jauaperi, Lower Amazon, and Lower and Middle Madeira River regions, territories populated by the Waimiri-Atroari, Mura, Munduruku, Mura Pirahã peoples, among others.

At the same time, a series of regulatory changes began to take place. In 1920, Alcântara Bacelar modified the state's agrarian legislation, instituting the provisional lease of vacant lands that contained Brazil nut trees. In the same year, he revoked law 941/1917, which he himself had instituted together with the SPI, regulating the allocation of land to indigenous peoples in the State of Amazonas. ${ }^{8}$ The new law suppressed the principle of recognition of the right of indigenous people to land. It placed any land concessions to indigenous families or tribes under the control and convenience of the state government. In 1921, the new governor, César do Rego Monteiro (1921-1924), not only suggested relaxing prohibitions on the sale of nuts, but also proposed a change in how nut groves were defined: "if one considers as nut groves [or circuits] to be any land containing small groups of not trees, (...) then almost all of the land is within this prohibitive definition". In Governor's opinion, defining the nuts as "a food resource for the poor [cannot] be a reason for the State to [impede] nut harvesting" (AMAZONAS 1921: 135/136).

In the wake of conflicts between factions in the state oligarchies, Rego Monteiro pushed one of the characteristics of the coronelista ${ }^{9}$ system to the limit: the interweaving of the state's governing apparatus with private interest networks. In mid-1924, the state government was deposed by tenentista ${ }^{10}$ forces who took Manaus and held power for about a month (SANTOS, E. 2001). From the end of 1924 until the beginning of 1926, the state of Amazonas would thus suffer under direct federal intervention as a result.

The 1920s, which had begun under the cloud of serious economic crisis, also saw a worsening in the regional labor shortage, especially in the 1923/1924 when the reactivation of the rubber plantations combined with the increased price of Brazil nuts to boost extractive enterprises in a very specific way (SANTOS 2009). On the one hand, Brazil nut groves were legally constituted as common areas for free extraction or as lands regulated by the community. On the other, the rubber plantations had been forced to loosen the mechanisms of their control over their laborers, expanding tappers' autonomy. According to Weinstein (1993: 274), "the very basis of the employer's economic and political power: his ability to extract a marketable surplus from the local population" was thus under threat. The resurgence of violence and attempts to subject indigenous peoples was therefore part of a broader process of reordering forces and strategies to immobilize the regional workforce and reconstruct a monopoly on the extraction of resources: most notably Brazil nuts.

\footnotetext{
8 Law 941/1917 authorized the state governor to "grant, as immemorial possessions held by primary occupation, all lands [then] owned by wild or semi-civilized Indians, for their residence and use" (caput). As demonstrated elsewhere (SANTOS 2009; 2014), the practical-symbolic resolution of this law led to the recognition of the territorial rights of semi-civilized indigenous peoples over limited areas of land destined for agricultural activities. It also referred to a unilateral act of the state - the reservation of land - and the possibility of allocating larger areas (more favorable to extractive practices) to so-called wild Indians. This created a norm grammatically linked to the civilizing project under which the interests of the SPI and the state executive were aligned. Law No. 1144/1920, which revoked Law No. 941, established in its Second Article 2 that the Governor of the State "would grant to indigenous families or tribes the area of land that in his discretion [he judged] convenient for the domicile and use of these families or tribes" (our emphasis).

9 Translator's note: rule by paramilitarized local elites through clientelist networks.

10 Translator's note: a progressive movement of the 1920 championed by the lower ranks of the Army's officer corps.
} 


\section{Methodological questions and scales of analysis}

When making his defense, Bento Lemos -- head of the SPI Inspectorate in Amazonas and Acre ${ }^{\text {- }}$ - emphasized that several of the protagonists of the Inquiry Commission (merchants, alleged landowners, alleged squatters, mayors, and police officers) were at the time (or had been in the past recent) in direct confrontation with indigenous peoples and representatives of the SPI (BRASIL 1931 Vol. IV). In fact, all those who had voluntarily filed complaints against the SPI in 1931 were in this category, as were several witnesses and some members of the Commission itself, particularly engineers with experience in demarcating land in indigenous territories (SANTOS 2009). ${ }^{12}$

This approach, based on my analysis of the diverse documents produced by the Inquiry Commission, ${ }^{13}$ indicates that the Inquiry should be read as a product of political interests, whose signs were manifest not only in the lists of investigators and witnesses, but also in the procedures the Commission adopted and in the construction of its court case. Particularly notable in this regards the absence in the Inquiry's transcripts of any testimony favorable to the Inspectorate and in the exclusion of the results of an extemporaneous investigation by the Commission, carried out in São Gabriel, which -- unlike all the others -- had concluded that there were indeed "true forest-dwellers" in the region (BRASIL 1931 Vol. IV). Nevertheless, the methodological and analytical option I adopt here is to suspend any distinction between "false" and "true" testimony. Complaints, statements, and defenses ate appraised equally as construction of "interested truths," produced for/by judicial dispute (BOURDIEU 1989). The interplay of the various versions of these "truths" exposed in the Commission's paperwork ends up showing the multiplicity of meanings and effects implied in the representations, relations, and social actions set before the Commission.

This allows us to discern at least three distinct situations in the scenarios under investigation. The first is a set of events referring to the strong resistance of indigenous peoples to attempts to privatize Brazil nuts. This resulted in outbreaks of violent conflicts in different regions of inner Amazonas, particularly in 1923 and 1924. The second refers to processes that we might call the restoration of order. These involve 'pacification' measures in the interior of the state, undertaken between the years of 1925 and 1927. Finally, between 1928 and 1931, we see an intensification of disputes for control of territory and indigenous labor. These sets of events are not only linked together as small social dramas, but are also discursively connected in the Inquiry Commission's documents. I call this the logic of defamation ${ }^{14}$ (SANTOS 2009).

Following the regional focus of my broader research and in view of the excellent results produced by microanalysis and shifting scales (REVEL 1998), events and narratives will be presented below through singular scenes, taken from testimonies given in the context of the Commission's questionnaires regarding the municipality of Borba and the lands occupied by Mura and Munduruku on the Lower Madeira River.

\footnotetext{
11 Bento Martins Pereira de Lemos, from Maranhão, headed the first Regional Inspectorate of the SPI between 1916 and 1932 , becoming an important agent in the institutionalization of the Service in the state of Amazonas and the territory of Acre. Under his administration, initiatives were taken to recognize indigenous lands and to legally defend these. Exploitation of indigenous labor by employers and private enterprises was also a concern of Bento Lemos' administration, as well as the census and regulation of indigenous tutelage. Bento Lemos produced significant documents such as letters, dense annual reports, and visual records. See, in this respect: FREIRE, 2007; MELO, 2007; SANTOS, 2009, Chapter 2

12 The Commission was chaired by engineer and surveyor Manoel Dias Barroso, responsible in 1923 and 1925 for the demarcation of plots in Munduruku lands on the Mari-Mari River and Igarapé Laranjal. Another of its members, Demétrio Hermes de Araújo, was an agronomist from a traditional family established in the Baixo Madeira/Amazonas. He had been denounced for irregularly demarcating two lots in Mura territory (Igapó-Açu) in 1928 (BRASIL 1931 Vol III).

13 In the research for the thesis that gave rise to this article, reports and official letters from the Indian Protection Service, messages from the governors to the Legislative Assembly of Amazonas, newspapers and publications of the time, from different collections in Rio de Janeiro and Manaus were analyzed. In this article, the examination of the records of the investigation itself has been privileged, although this analysis is also based on this broader set of documents (SANTOS 2009).

14 Translator's note: the lógica da detratação in the original. Literally, the logic of "mistreating" or of mistreating through intentional attacks on the reputation of the target.
} 
This region's economy was deeply linked to the exploitation of rubber and Brazil nuts at the time (BRAZIL 1913) and we can thus presume that this regional focus maintained connections with the broader political spheres involved in the Inquiry Commission's attack on the Inspectorate. The local inquiry itself took the form of a great "legality ritual", performed by a local commission presided over by the judge who prepared the charges. This "ritual" traveled through the main indigenous and Brazil nut territories of the municipality in question, questioning witnesses and future defendants. ${ }^{15}$ The map presented below locates some of the areas visited at that time. These are indicated by the presence of the Cunhã-Sapucaia and Arari Indigenous Lands (TIs) to the left of the Madeira River and the Setemã and Coatá-Laranjal TIs to its right. ${ }^{16}$

Map of indigenous lands and conservation units in the Legal Amazon, March 2019, Instituto Socioambiental. Highlighted: Cunhã-Sapucaia, Arari, Setemã, Miguel/Josefa, and Coatá-Laranjal Indigenous Lands.

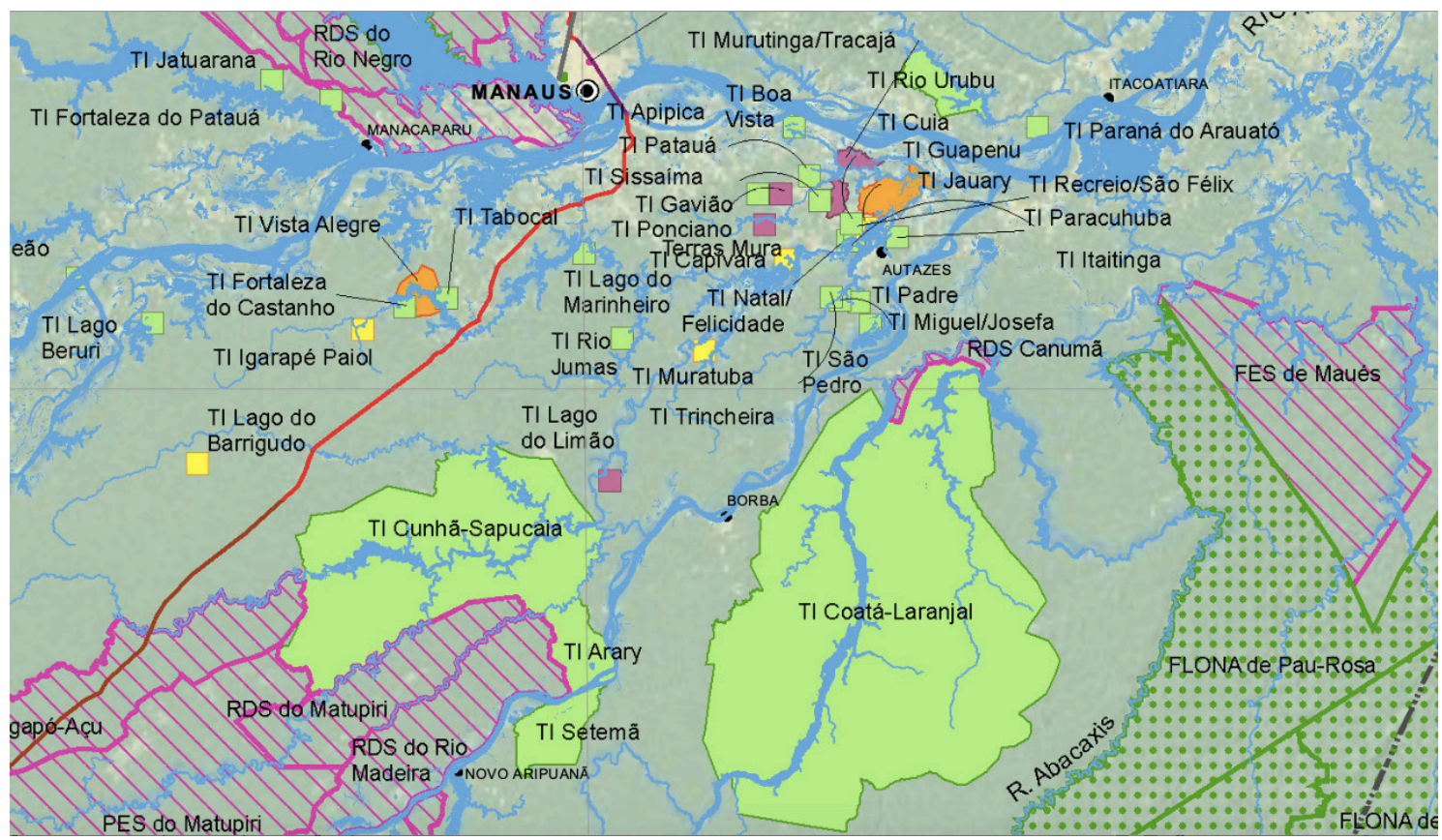

15 The inquiry carried out in Borba stands out from the others. In addition to concentrating many of the complaints against Inspectorate officials and indigenous police officers, present in significant numbers in the municipality, the local authorities paid particular attention to the Inquiry, for which they mobilized a notable investigative apparatus. Answering the questions elaborated by the Commission of Inquiry in Manaus gave rise to the creation of a small committee, coordinated by the judge preparing the report and integrated into the highest levels of the municipal executive branch. A boat provided by City Hall took members of this commission up several rivers throughout municipality so that they could question, in loco, residents of places close to the villages, Indians, and SPI employees. An ad hoc report was written by the mayor himself -- Sérgio Pessoa Filho - who had inspected incidents in nut groves in areas occupied by indigenous peoples shortly after his appointment as military mayor, even before Act no. 193 (SANTOS, 2009).

16 The map depicts the Lower Madeira River and its tributaries around the Autazes lakes, a complex of channels near the confluence of the Madeira River with the Amazon, a floodplain area that constitutes the Mura's territory, where several regularized Indigenous Lands are situated. Going up the Madeira River from the municipality of Autazes towards Borba, one encounters some of the localities/regions mentioned in the article: the Cunhã nut circuit, occupied by Mura (Cunhã-Sapucaia TI); the Miguel/Josefa TI, where the Josefa Indigenous Post was established in 1928; the Setemã, Aranaquara, Arari and Jacaré villages, areas of Mura occupation on the banks of the Madeira (Arari TI on the left bank, and Setemã TI on the right bank); and the Canumã-Abacaxis interfluvium region to the right of the Madeira, where the Paca, Laguinho, Cipó and Laranjal villages are situated with reference to the Coatá-Laranjal TI, occupied by the Munduruku and Sateré-Mawé (INSTITUTO SOCIOAMBIENTAL 2019). 


\section{Scenes from the conflict}

Odorico Ferreira Chaves - a farmer from Pará, 62 years old, married, living since 1902 in Boa União/Rio Preto do Igapó-Açu, Autaz region - was questioned as a witness by the Borba commission regarding the first territory they investigated: the Cunhã nut grove, located on the Preto do Igapó-Açu River, where the Inspectorate maintained a village of Mura Indians. That year's harvest had been administered by civil police officer on leave, José Sant'Anna de Souza. In his testimony, Chaves agreed with the assertion that there were no real forest-dwellers in the region, nor any village regulated by the Inspectorate. He also denied that the person "responsible for the Inspectorate's lands" had extended his activities beyond the Cunhã site. Called to justify his position as a Indian police officer ${ }^{17}$ before the Commission, he explained that the Mura were the native caboclos ${ }^{18}$ of the region who, although "already mixed", lived a "more needy life than others" (BRASIL 1931 Vol. I: 236v).

Chaves' posture of active work with the SPI and with the indigenous peoples of the region is quite apparent in the documentation relating to the previous years. In 1928, he was asked to respond, as an Indian police officer, to a series of protests by the residents of Igapó-Açu who claimed that the Indians held numerous possessions and nut groves in the region. In the same year, Chaves went to Manaus accompanied by some Mura Indians to personally deliver to Governor Efigênio Sales a report regarding the occupations of the indigenous people and the "poverty" of Igapó-Açu. Also in 1928, he demanded a series of measures aimed at reinforcing the local presence of the Inspectorate from the SPI. These included the inauguration of a school - which Chaves was willing to work in as a "teacher of elementary reading and writing" and a suggestion that General Rondon visit the region (SANTOS 2009).

In 1923, along with twenty-seven other residents of Autaz-Açu, Odorico Chaves addressed a petition to then-Governor César do Rego Monteiro, denouncing attempts to usurp lands occupied by the Mura indigenous people along the Igapó-Açu, Tupana and Autaz-Mirim rivers (SANTOS 2009). Some witnesses in the 1931 inquiry complained that they had been expelled from their occupations in these places that year by "neighbors (...) [who] called themselves Indians" (BRASIL 1931 Vol. I: 222). Two years later, in 1925, Chaves would be accused by the police deputy of the 1oth District of Borba - his next-door neighbor, "compadre and friend" - of leading an "uprising" of Mura Indians in Igapó-Açu "with the purpose of disturbing public order and preventing measurement and demarcation services on lands required by several people" (BRASIL 1925). The Inspectorate was obliged to carry out an operation in the region to investigate the complaint.

It is important to note that, also in 1925 , Odorico Chaves gave shelter, on his own land, to Mura from the Setemã, Aranaquara, Arari and Jacaré villages, located in areas along the Madeira River which were being claimed by the owner of the Vista Alegre rubber plantation, Colonel Augusto Costa. Indigenous people were fleeing the persecution organized by the colonel and his son-in-law, sub-delegate Luís José Soares. Since at least 1922, both of these men had been restricting the Mura's free access to nut groves and to lakes and other resources. The climax of this conflict came in 1924, after a confrontation that resulted in the death of a worker and the surveyor subcontracted to demarcate the lands next to the villages. That year, Natives encircled the Vista Alegre trading post for approximately one month. Through José Guimarães - the manager sent by the Inspectorate to manage that year's nut harvest - they had effected the arrest two men linked to Colonel Augusto Costa. These were sent to a Manaus, then under tenentista control. Months later, the villages were the target of violent punitive incursion, carried out by police officers and Augusto Costa's men. Women were raped in these attacks and other Natives were beaten, imprisoned, taken to Manaus, and later convicted of murder (SANTOS 2009).

\footnotetext{
17 The delegado dos índios, or Indian Police Officer, was an unpaid SPI position, established in regions where formal SPI posts had not or could not be situated. It kept the Service abreast of occurrences in the region.

18 Translator's note: people of mixed Indigenous and European ancestry.
} 
In 1925, Augusto Costa accused Odorico Chaves of "making the caboclos into hired thugs" and of having organized with indigenous leaders and José Guimarães himself the actions that had resulted in the deaths and imprisonment of Costa's men in 1924. Costa asked the Inspectorate to investigate the conduct of the Indian police officer (SANTOS 2009). In 1931, Luís José Soares brought this to the Commission. Demonstrating that there were no Native in Vista Alegre - only "caboclos, but civilized", he sent a series of documents to the Judge in Borba, including a letter dated June 1930, in which Colonel Costa requested Inspector Bento Lemos' "resignation from the position of Indian police officer" (BRASIL 1931 Vol. II: 266). The official letter was in fact a response to a previous request from the Inspectorate, which asked the Colonel to inform them about the date of the installation of the Indian police station in those lands, indicating "the known Indian malocas, verandas, rivers, streams, lakes, civilized encampments, centers of extractive industry (rubber, balata, caucho, nuts), natural fields, etc." (BRASIL 1931 Vol. II: 265). It is interesting to note that a Protectorate school had been operating in Vista Alegre at least since 1927, whose teacher was Corina da Costa Soares, daughter of Colonel Augusto Costa, married to Luís José Soares.

The Abacaxis District - the region of Munduruku occupation where the Laranjal, Paca, Laguinho and Cipó villages were located, on the right bank of the Madeira - was the third place to be visited by the local inquiry commission in Borba. Some of the municipalities main nut groves were in this region, and it was thus not by chance that it had been chosen in 1929 for the establishment of an Indigenous Post. ${ }^{19}$

In 1931, the person in charge of this Post, Raimundo Venâncio da Costa Leite, nephew of Bento Lemos, testified before the local commission of inquiry, along with three Munduruku, Militino de Souza e Silva (an Native police officer since at least 1925) and Manoel João dos Santos (Captain of the Laranjal, Laguinho, Paca and Cipó Indians). The main subject of this investigation were the practices surrounding the supply of and commercial exchanges at the post. The monopoly on the sale of Brazil nuts and other products, established with the installation of the post, was firmly defended by Raimundo da Costa Leite as a measure aimed at protecting the indigenous people and one of his main duties as post supervisor. Nevertheless, the indigenous people themselves showed some discontent with this position, pointing out the breach of commitments made by the post and the disadvantages of having to work with pre-fixed prices without being able to "sell their nuts to whoever gave the best price" (BRASIL 1931 Vol. I: 252). There was consensus regarding the scope of the supervisor's activities, which everyone described as limited to the duly demarcated area. The witnesses also agreed that there were no "true forest-dwellers" in the region.

Along with Inspector Bento Lemos, the person in charge of the Laranjal Indigenous Post was one of the SPI employees most severely attacked during the investigation, being the target of several accusations sent directly to Manaus. In response to these allegations, the Defense carefully recovered, in its documentary appendix, the long history of conflicts and land disputes involving the Munduruku and generations of the same oligarchic family group - the Pessoa Sobrinhos - which had been occurring since at least the middle of the 1910s (BRAZIL 1931 Vol. IV). In the early 1920s, the intensification of these disputes was revealed in several Native initiatives: 1922 was the year in which Militino de Souza e Silva "founded" the Laranjal village, building a wattle and daub chapel in it and requesting that the Inspectorate demarcate the area in his name.

19 The Laranjal Indigenous Post was located at the confluence of the Paca River with the Mari-Mari, a tributary of the Abacaxis River, in the midst of other Munduruku villages spread throughout its interfluvial region with the Paraná do Urariá and the Canumã Rivers. It was certainly one of the main nut producing areas in Borba, as Mayor Sérgio Pessoa noted in his report. The area under the influence of the Post contained three other nut groves with a total production of between 1000 and 1500 hectoliters, in addition to the Laranjal itself, with a production between 600 and 800 hectoliters 
There were also attempts to by merchants, civil servants, and rubber tappers to advance into the territory, such as those that materialized in 1923 in the form of requests for land demarcation. These were sometimes followed by violent incursions and arbitrary arrests (SANTOS 2009). In 1924, conflicts exploded in the region around the Canumã River (also under Munduruku occupation), with a series of trading posts being besieged and ransacked by the indigenous and non-indigenous people living along the river. The episode was described in 1931 as "the famous revolt on the Canumã River and its tributaries, in which several people died, and all commercial establishments were looted” (BRASIL 1931 Vol. I: 247V/248).

In 1928, there were new attempts to privatize nut groves in the Laranjal region, as shown in five different land applications from the Pessoa Sobrinho family. At least one of these was recorded as resulting in a direct confrontation between indigenous people and the family's workers. The episode was followed by a police incursion that besieged the home of a Native in the Paca village. In the documentation, it is sometimes described as "robbery of the trading poet", sometimes as a seizure of property for payment due to the indigenous people. In that same year the Inspectorate refounded the Laranjal School. In 1929, it installed the indigenous post and demarcated two "lots": Laranjal and Chiadá, the latter located on the Canumã River. In the mid-193os, Raimundo Costa Leite, in charge of the Laranjal Indigenous Post, would undergo a police investigation, being blamed for the cruel (and false) murder of a Munduruku man. ${ }^{20}$ In the same year, he was also the target of an aggressive public repudiation campaign, expressed in a manifesto signed by no less than 102 district residents (SANTOS 2009).

\section{Restoring order: narratives of defamation, legality, and violence}

The events that formed the basis of the 1931 narratives thus date back to the early years of the 1920s, a period strongly marked by the rubber collapse, the increasing value of Brazil nuts, and the transformations of extractive enterprise in the Amazon. Far from being incidental attacks on extractors and their resources, these changes involved the privatization of Brazil nuts and destabilized the entire local productive system, directly threatening the occupations and autonomy of extractors - indigenous and non-indigenous - and small traders. The conflicts reveal the strong resistance to strategies that finalized the (re)composition of commercial monopoly over land and resources that had remained tangential to the rubber economy and which had continued, up to then, to be accessed by "the poor". It is necessary see the records of "turbulent gangs plundering and destroying the property they found along their way" in the light of this process (AMAZONAS 1923: 17/18) and likewise, inversely, the initiatives to defend access to resources and territories whose paths said "properties" insisted on obstructing.

The uprising in Canumã and the siege of Vista Alegre in the critical years of 1923/1924 suggest that the conflicts went beyond reactions to localized disputes, taking the form of a broader resistance. The strength of this movement seems to have resulted from the organization of multiple local networks with significant and fundamental participation of indigenous people, but also including other subaltern sectors of the population (SANTOS 2009). In this process, the role of the SPI Inspectorate stands out, especially through its Indian police stations. The Inspectorate was building alliances that served to produce information and affirm the agency's presence in territories where the strategic distribution of resources had not yet permitted the installation of local administrative units (SOUZA LIMA 1995).

20 Under the terms of the defense documents produced by the Inspectorate, a Munduruku person had been taken to the village of Cipó, the residence of his family, where he had died of severe fever accompanied by delirium. He would have been ritually cremated by other indigenous people (BRASIL 1931 Vol. III: $733 / 733 \mathrm{~V})$. The false accusation of murder against Costa Leite was based on statements obtained from seven Munduruku who were arbitrarily arrested and held in prison for seven days. 
The stories of Odorico Chaves and Militino Souza e Silva suggest that it was through the Inspectorate's connection to these subaltern sectors, which were under severe pressure, that the agency first implemented its activities in these regional contexts, marked by strong disputes. For the Mura, the Munduruku and the non-indigenous groups linked to them, the Inspectorate represented access to more-or-less institutionalized channels of federal administration and, through this, state administration. In the resistance to the privatization of the nut groves, this was an important consideration. It infused demands, denunciations, and actions with legitimacy and created concreate entries into the legal field. These, in turn, could result in effective measures carried out by state agents. In certain contexts, such agents started to function as alternative networks of commerce, protection, and power, providing access to the State in a parallel or opposite way to the networks articulated around oligarchic coroneis.

A dimension that must be further investigated is that of the relationships and mutual effects between the confrontations described above and the political developments in Manaus. The tenentista rebellion in the state capital was mainly associated with external factors and agents, with its local face based on dissatisfactions emanating from an urban context (SANTOS, E. 2001). From a general perspective, the simultaneity of these revolts does not seem fortuitous, suggesting awareness and political action on the part of the Natives and their networks, as well much deeper ruptures in the emergence of the tenentista movement than those caused by the arbitrariness of the Rego Monteiro Government. After the defeat of the rebels and the arrest of the movement's principle leaders, the need for federal intervention became the consensus among state political actors. The restoration of order was turned into a social necessity, shaping the more immediate context of the conflicts that unfolded at the beginning of the decade.

Aimed at cooling down the disputes and tensions that had erupted over the previous years, the actions of the Inspectorate accompanied the restauration order. In 1925, Bento Lemos informed the Federal Intervenor of the situation of the indigenous lands threatened by the advance of extractive enterprise. He observed that, due to the dispossessions perpetrated during in the previous year, the Inspectorate had been forced to send numerous missions to the interior with the aim of "restoring normality in the villages and calming the spirits of the Indians who remained revolted by attempts to occupy their lands" (BRASIL 1925a: 02). Letters and reports with different objectives and degrees of formality (VIANNA 1995) describe the diligence of the Inspectorate in Igapó-Açu, clearly showing the existence of a performative dimension in these acts of restoring order (SANTOS 2009). The Federal Intervenor then seemed to ensure that the SPI would retain a certain amount of political capital.

In terms of its programs, the Efigênio Sales Government (1926-1929) had many similarities to that of Alcântara Bacelar, investing in the "civilizing" and "ordering" effectiveness of public education and agricultural rationalization. ${ }^{21}$ There is, however, a clearing away of the Inspectorate's real political power: the body would no longer be the preferred partner of the state government in implementing "civilizing" projects. The Catholic Church, as well as landowners and civil entities, emerge as important agents in (for example) the creation of schools, a policy with well-known territorializing goals. ${ }^{22}$ As far as the Inspectorate was concerned, the initiatives taken to "maintain order" lost their performative dimension, becoming increasingly substantive commitments to local bosses and oligarchs. This can be seen in the appointment of Augusto Costa as an Indian police officer and in the founding of a school in the Vista Alegre plantation.

21 Professor Sales pushed basic education, reconstructing the network of public primary school in inner Amazonas, which had been losing units since 1912, when it had 270 schools. In1923, only 123 of these were left, to which Federal intervention added another. In 1929, the last year of the Salles government, there were 278 schools (AMAZONAS 1929: 217).

22 The policy of creating and maintaining new schools in the interior of Amazonas was particularly dear to the Governor, who claimed that in this region "the child population is very widespread and not very sedentary outside the cities and towns". Salles attributed low average attendance at schools to the "almost nomadic life of the extractor", which inevitably led to the interruption of the children's school activities. He projected a future in which school attendance would surpass $80 \%$, when "the country population of Amazonas was tied to the soil by agriculture or by breeding, as in part is already being done" (AMAZONAS 1928: 6o;67). 
This scenario illuminates some of the testimonies and denunciations that made up the 1931 Inquiry. In these narratives, conflicts appear displaced from their contexts. They are described not as a call for help in the midst of a crisis, but as part of later processes of defaming political opponents: the indigenous and non-indigenous actors connected to the Inspectorate. There is an accusatory principle at work in this logic, aimed not only at criminalizing, but also at delegitimizing, belittling, diminishing - defaming, in short -- the value of certain people's words and the scope of their actions. The Inquiry sought to eliminate these actors from the circuits authorized to produce truth regarding the facts, reducing said actors' capacity to promote actions that validated and defended their interests. The accusations made against Odorico Chaves in 1925 by a neighbor - that he organized an "uprising" in Igapó-Açu - is exemplary in this sense. The Inquiry can thus be seen as an "idealized plan" that was intended, as the procedure concluded, "to alienate the authority of the officer of the Inspectorate and displace the Indians from that region, so that the complainant [could] take charge of Igapó-Açu village (nut groves) and facilitate the occupation of Cunhã" (BRASIL 1925: 5/6, our emphasis).

If we observe that the complainant was a police sub-delegate, we see that both defamations and praise constitute a dialectic, aimed at building legitimacy for the extralegal exercise of power (SANTOS, 2009). Public functions and positions carried significant degrees of prestige for their occupants, in addition to the possibility of accessing the resources essential for the exercise of domination - information, police power, the operation of justice, economic benefits (CARVALHO 2005).

At this point, it is necessary to emphasize that "order" and "violence" were not antagonistic realities: as two sides of the same coin, the construction of legal pretensions was deployed for the arbitrary use of force. As Emmi (1987) points out, in an extractive mercantile economy the determining factor is not land ownership but rather commercial capital, as this establishes control over land and transport, guaranteeing labor (production) and commercialization. Such control does not require strict ownership of land. As Pacheco de Oliveira (1988) shows when describing the "situation of rubber plantations" among the Ticuna in the early 2oth century, the imposition of a commercial monopoly was associated with claims of ownership over lands strategically located to allow control over large territories inhabited by the indigenous people, who were then transformed into vassals.

In the land conflicts of the Baixo Madeira, the construction of this alleged legality is perceived as being endorsed by the officially transmitted legitimating word. A sketch attached to the records of the investigation shows the occupations that took place in the Rio Mari-Mari region (BRASIL 1931 Vol. II). The Munduruku villages of Paca, Laguinho, Cipó and Laranjal appear interspersed with "private properties, claimed by the State Government", almost all also claimed by members of the Pessoa Sobrinho family (our emphasis). This family sought, in its own words, "to regularize their situation in the Rio Mari-Mari" (our emphasis). The geographical arrangement of the claims shows the very clear intention to isolate the nut trees and subject the indigenous peoples: 
Map indicating nut groves and the Munduruku villages of Pacas, Laranjal and Cipó (marked in red). Lots requisitioned or regularized by third parties are marked in green. Source: BRASIL 1931 Vol. II



Although expressed as mere reports, such statements (written in an apparently descriptive and referential language) quickly acquired the air of acts of institution, of naming, as stated by Bourdieu (1989) in referring to the performative character of the public, authorized, official word. The judge's verdict is the form par excellence. In fact, as soon as they had access to a stage for formalizing their "rights", the Pessoa Sobrinho family set up trading posts at both ends of the area they intended to rule. These were the headquarters from which they launched, in subsequent harvests, the battles for the territory's sovereign conquest.

The process of imposing dominion, meeting requests, granting concessions, titles, and fees, and collecting territorial taxes made it possible to remove the arbitrary violence committed against the indigenous peoples from view. The process becomes an alibi for violent actions, extending the opportunities and limits of these actions. It is no wonder, then, that the Efigênio Sales Government would promote a comprehensive reform of the state's land legislation as part of its efforts to reorganize the Amazonian interior. The Government argued that the legal dimension of property should be a stimulus, not an obstacle to economic activity (SANTOS 2009). The working hypothesis we have developed elsewhere points to a flexibilization of the rigid norms instituted during the federal intervention of 1925 , reinforcing the legal bases and bureaucratic procedures favorable to strategies of territorial usurpation and imposition of domain (SANTOS 2009). Continuing Emmi's (1987) reasoning, we can perhaps say that, in a mercantile extractive economy, it is better to have a "reserve of legality" that can be applied to contextually valued territories and resources, rather than to have a guaranteed, legal reserve of land in the strict sense.

The second half of the 1920 sould be characterized by the resumption of the downward trajectory in the price of rubber and by the instability in Brazil nut prices, which. Even so, the nuts consolidated as the premiere product among the region's exports. By 1928 and 1929, the final years of the Sales Government, an already depressed economy is at the end of its rope. This is when concern with disorder in the interior of the state reappears in official messages (SANTOS 2009). In fact, during this period, there was a resurgence of conflicts in the indigenous territories of the Baixo Madeira. This resurgence was associated with the same strategy of 
subjecting the labor of semi-civilized Indians, then being renewed by their "stability in penury". However, it also reflected the practical effects of a new federal norm: Decree 5484/1928, which regulated indigenous tutelage (SOUZA LIMA, 1995).

\section{New conflicts and classificatory disputes}

To understand this third scenario produced by the 1931 narratives, it is necessary to understand that, in Amazonian land disputes, the construction of legality did not dispense with some kind of factual engagement with the territory "on the ground" so to speak. In addition to violence, this engagement was also based on more-or-less fortuitous alliances with local authorities and residents. These, in turn, produced small private forces capable of controlling territory and/or asserting land ownership and -- more importantly -- use of the residents of the land as workers.

These so-called pre-posts were thus the real forces of territorial occupation, including for the Inspectorate. In this sense, compromise solutions along the lines of indigenous schools and police stations involved a geopolitics of territorial occupation. This could be a tactic of advancing indigenous interests, even when carried out in association with known indigenous oppressors such as Colonel Augusto Costa. By regulating Native tutelage and infusing the actions of the Inspectorate with legitimacy Decree \#5484/1928 contributed to tactically repositioning the SPI's interests and dispositions, strengthening direct interventions in land management and in the administration of Indians. Between 1928 and 1929, the Inspectorate demarcated five lots in the Baixo Madeira: Onça, in Lagos da Josefa, Miguel and Sampaio; Cunhã, in Igapó-Açu; Laranjal and São José do Cipó, on the Rio Mari-Mari; and Chiadá, on the Canumã River. In addition, the SPI founded Indigenous Posts and schools (Laranjal and Lago da Josefa) and placed administrators in Brazil nut groves (Igapó-Açu and Canumã). It even incisively imposed a commercial monopoly on the indigenous people. Conflicts were therefore renewed, and the geopolitical and symbolic dimensions of the disputes became ever more intertwined.

Returning to the proposition about the praise/defaming dialectic as an accumulation of legitimacy for the extralegal exercise of power, it is not surprising that the most way to convert the authorized word into power for action was rooted in the instrumentalization of police forces. Small private armies (which, when not effectively employed in open confrontations or punitive expeditions, served to intimidate) often relied on the participation of the agents of the State's public forces. Such practices had a general meaning that went beyond the co-option of armed forces to increase military power. Police agents imputed their authority and public functions to the private production and commerce networks with which they engaged. Persecutions determined by private interests were transformed into State actions and the violence exerted against the Indians became a classificatory act. ${ }^{23}$ It is no wonder, then, that some of the administrators authorized by the Inspectorate to manage indigenous nut groves were also police agents.

The Inquiry's practices extended the scope of the instrumental use of the police in violent actions against indigenous peoples. It expanded the target to include the representatives of a governing body (the Inspectorate). It created legitimacy for the physical force arbitrarily employed in territorial disputes. Complaints were filed in 1925 against the Mura and Odorico Chaves in Igapó-Açu and Madeira. In 1927, by order of the Chief of Police, an inquiry was launched in the village of Canumã against a trader who had allied with the Munduruku in 1924. It was during this investigation that the State established that no "real forest dwellers" existed in the region (BRASIL 1931: Vol. II page 509). In 1928, the Tuxaua and Mura Captain from the Onça lands in the Josefa region,

23 José Murilo de Carvalho (2005) calls attention to the economic dimension of this political control of police power and administration of justice through the distribution of public offices: the judge and the police officer, he observes, were important for the control of the workforce and, therefore, for economic competition, with the ability to oppress and protect one's own workers as crucial as that of being able to persecute the workers of others. 
close to Madeira, were forced to sign an "agreement to live properly". ${ }^{24}$ But nothing better reflects this double constitution of physical and symbolic violence than the 1929 inquiry initiated into the false murder of an indigenous man and attributed to Raimundo da Costa Leite. The discourses created by this inquiry were constituted by and through the crudest physical violence (the imprisonment, coercion, and forced labor of seven indigenous people who were thus transformed into witnesses) via the magical authority of the written word (the reading, in prison, of newspaper stories about the alleged murder) and the threat of extralegal power as adjuncts to the constituted public authorities (BRASIL 1931 Vol. III).

To make a long story short, after the clashes of 1923 and 1924, repressive activity was closely linked to the defamation of indigenous people, indigenous police officers, and those in charge of indigenous posts. Up to the beginning of 1931, initiatives were taken to gather formal complaints against Indians and Inspectorate employees. This movement began at the end of 1930, possibly as a result of post-revolution political arrangements. In 1931, these denunciations were mentioned, suggested, dismissed, re-enacted, and ultimately re-appropriated as evidence for the production of certain truths. There is a sense of timing in this logic of defamation ${ }^{25}$ The Inquiry into the Indian Inspectorate did not, in fact, represent a new attack against the Indian Protection Service in Amazonas, but rather the acquisition, by the Service's detractors, of a new level of legitimacy.

\section{Neither true forest-dwellers, nor good citizens}

The Inquiry into the Indian Inspectorate was nourished by a climate of revenge by technical action versus political action, the latter being associated with the fallen Republic. It counted upon the support and knowledge of specialists, the engineers/surveyors. It was guided by a set of objective questions (the questionnaire), which, at least in the municipality of Borba, were answered only after analyzing abundant amounts of information gathered and analyzed transparently in loco through direct observation or via witnesses who knew the local reality.

Nevertheless, a political production emerged from the analysis, tortuous in terms of recording the facts, but clear in terms of defending the economic interests of certain groups and social sectors. It was necessary for us to suspend questions about what was true and the false in these records so that we could detail their content. We now must return, however, to the question of the production of truth, for this is what qualifies the Inquiry as political theater and an act of power. What were the truths produced by the Inquiry? What were the representations and categories made explicit in it?

As already noted, one of the main mechanisms instituted by the Commission of Inquiry in Manaus consisted in the preparation and distribution (to authorities in the interior) of a set of questions regarding the presence of indigenous groups in the Amazon, and the nature and scope of the activities of Inspectorate's representatives among them. The first and central question -- whether there were "Tribes, Hordes or Settlements of true forestdwellers, as such recognized under the terms of current legislation and the Civil Code" and where these were located -- clarifies the content and scope of "Indian" as a category and the place of the authorities to pronounce upon the veracity of this category. In its final report, the Inquiry Commission maintained that the Inspectorate, to the detriment of the "true forest-dweller" population of several rivers in the State of Amazonas, took pains to register Indians in Manaus, Itacoatiara, Borba and Manicoré, municipalities where "true forest-dwellers" did not exist according to the Commission's records (SANTOS 2009).

24 The "agreement to live properly" was a kind of public commitment taken on by those who potentially threatened public tranquility (drunkards, bums, prostitutes, etc.) and, until 1832, also by those legally suspected of intending to practice a crime (COELHO 2004). In the case analyzed here, the Mura were forced by the Police Chief of Borba to sign a public commitment that obliged them not to return to their lands.

25 Dinamérico Pessoa, for example, (re)presented the complaint to the Police Headquarters against the "assault" on his post by the Munduruku of the Mari-Mari River, attesting to the direct and personal participation of Bento Lemos in the execution of the "crime". 
In fact, in the statements taken in Borba, not a single one affirmed the existence of "true forest-dwellers" in the places under investigation. The data reflects the effective formulation of the question. This sought to distance the meanings recognizable in the daily lives of the witnesses from the set of possible legally guaranteed categories (Indians, forest-dwellers). The expression "true forest-dwellers" exposes the premeditated and rational use of terms in these legal disputes. Interpretations of reality that are much more complex and rich in associative terms and which explained everyday knowledge (such as a certain condition of poverty, belonging to the place, descent) only appeared in these documents as quaint "asides", since they were already inadmissible given the legalistic formulation of the question. ${ }^{26}$ The asymmetry of power and competence inherent in the rite of questioning of witnesses must also be added to the limits set by the question.

A series of characteristics that are still present today in common sense as diluting the indigenous condition - miscegenation, mastery of the Portuguese language and other cultural skills - were used by the witnesses to distance the Mura and Munduruku from "forest-dwellers" and categorize them as "caboclos" or "civilized". Two sets of images attract attention here. First, there is socio-spatial organization: the indigenous families of those regions are already "organized" and "regularly constituted", so that each one had its own possessions. They did not live "in Native villages" ${ }^{27}$, nor "at the expense of the Inspectorate", but by the fruits of their own labor, in "their places near trading posts and plantations". Second, there is the exercise of civil and political rights. Voting, participation in the Judiciary, the National Guard, or the Army, knowing how to read and write: all these things qualified the "indigenous descendants" of Borba as "civilized" and thus "not really Indians". As one witness put it:

...among those who call themselves Indians in Canumã and in Sampaio one finds voters and jury members and today only the oldest natives speak their tongue, but the youngest and all of them speak modern Portuguese, and protest in favor of their rights as any citizen and have organized families... (BRASIL 1931 Vol. I: 244).

It is interesting to note that the deconstruction of the Mura's indigenous condition - woven from supposedly technical and objective criteria - was accompanied by a silent work construction, which was strongly valued. Their mischaracterization of the Mura as Indians was not accompanied by an objective or ordinary characterization of them (as Amazonanians, for example). Defamation gained support from small shifts in meaning. Frequently, the marks of civilization itself were used to deconstruct Indigenous people as such. Alongside the mischaracterization of the inexistence of villages, defined in "technical" terms as "three structures set far apart" (for example), we also find evaluative descriptions that describe existing Native occupations as unworthy of "true" Indians. The "so-called" village of Cunhã, emphasized in the report prepared by the judge in Borba, "didn't [actually] exist", since in addition to the shack that served as the residence of the Inspectorate's manager, the settlements other structures were "huts that are well spread apart" (BRASIL 1931, VI, page 183). One whistleblower described Laranjal as "pompously called a village of Indians and which serves as a reason to drain away the Nation's money":

...[I]t's a thin strip of land useless for any kind of cultivation where the native MILITINO so-and-so resides, with two huts in which he lives with his family and where he has built a crude thatched chapel which he says will be the center of a nut grove that he demanded be regularized in May 1928... (BRASIL 1931, V. I, fls. 276V/277, our emphasis).

26 This effect immediately stands out in the reading of the testimonies, repeatedly introduced by a formula already established by the initial statements: "he said that there are no savages in this entire region (...), because the descendants of the Indians who live there..."; "he said that despite knowing all the rivers in this region, he never saw wild Indians anywhere, and he only knows a few descendants of Mura Indians...” (BRASIL 1931 Vol. I: 219/220).

27 The existence of indigenous villages was the object of the second question, formulated according to the same restrictive logic as the first: a generic association between "villages" and "dependence" being insufficient, the decision was to establish, in the question itself, that they would only be considered as indigenous those "groupings" which had been "regularly constituted" by the Inspectorate. 
A second operation can be found in the moral, appreciative valuation of those who were presented - or presented themselves - as harmed by the territorial actions and pretensions of indigenous people and the Inspectorate. The main authors of the narratives contained in the records - both authorities and complainants - described themselves as "upright men" while describing Indians and other poor groups as "criminals" or "hapless victims". The moral superiority of the authorities and witnesses was of fundamental value to the Inquiry as a device for the production of truth. The constant reference to noble and "regular" economic activities, the recourse to the performance of public functions, and the proper compliance with legal formalities (regularization requests, payment of fees and taxes) highlighted the immorality, uselessness, and irregularity of the defendants: the Indians and Inspectorate. ${ }^{28}$ Here we see the link between social hierarchy, morality, and legality being powerfully reaffirmed.

The criminalization of the Indians became a necessary component of this construction: an inevitable consequence and a kind of symbolic corollary. It was evident in the use of expressions that operated in a "natural" way to equate the terms Indian and criminal. They also equated Native territorial defense initiatives with crimes, transforming indigenous people into "looters", "supposed Indians", "robbers", "individuals who on that occasion called themselves Indians", "who only call themselves Indians when they want to take the place of others or when they commit some crime", or "civilized caboclos and smart-asses" (BRASIL 1931 Vol. I:181; 222; 233/233V; 244V; Vol. II: 519). This field of illegality/immorality/illegitimacy quickly began to incorporate the Inspectorate: Indian police and supervisors were the "pseudo protectors of Indians" and the "true clandestine traders" (BRASIL 1931 Vol. I: 247V/248; Vol. II, fl .514). The portrait that the "peaceful, calm and orderly people" of Abacaxis made of Raimundo Costa Leite described him as a "disgusting creature", given to the practice of "theft, crimes, and bad habits", which should be banned "for the sake of the morality, decency, and tranquility" of the region (BRASIL 1931 Vol. I: 185v to 186v).

It is clear here that, with regards to the Mura, Munduruku, and the Inspectorate, the defining categories of criminality are meant to be read as carrying essential truths, and that, therefore, these groups were justifiably the targets of police intervention and control.

\section{Final considerations: the power of classification}

The analysis presented above leads us to conclude that disputes over the power to categorize, classify, and - consequently -- define and control the administration of the Brazilian Indians, their lands, and resources constituted a key dimension of the territorial conflicts that erupted in the 1920 s and ' 30 s in the Baixo Madeira.

The new level of this dispute, the Inquiry itself, provides us with a measure of the impact caused by the enactment of Decree 5484 in 1928. In addition to assigning the SPI as the legal guardian of the indigenous peoples, the decree determined that the Inspectorate should proceed to conduct a census of the Indians, a task begun in Amazonas in 1929 and which was particularly advanced at the end of the following year in the municipalities of Manaus, Itacoatiara, and Borba. For Inspector Bento Lemos, this was simply the result of geography, the work being naturally faster in the areas closer to Manaus. For the Commission of Inquiry, it was (as said above) a clear indication that the agency ignored its responsibilities in civilizing the "true forest-dwellers" in favor of registering "false Indians" and installing them in nut circuits, thus gaining control of important resources and labor pools.

28 This prevailed in the larger survey while it remained at the state level. The deconstruction of the integrity and exemption of witnesses, promoted by the defense of Bento Lemos, was incorporated into the investigation after the final report. Lemos claimed curtailment of his right to defense (BRASIL 1931 Vol. IV). 
But, above all, the Inquiry's supporters feared that the Inspectorate had come to control a powerful instrument for defining reality: legal and administrative control over the civil registration of Indians. A true State action that would allow the SPI to "recruit the already civilized as Indians", cataloging them, registering them, assigning them a tribe, and "pushing them into native huts through the summary process of the census" (BRASIL Vol. I :304).

In February 1930, Inspector Bento Lemos had sent to Bezerra Cavalcante, Director of the SPI, a Memorandum on how to carry out the Indian census in Amazonas, Acre and the North of Mato-Grosso, as instructed by Mr. General Rondon. This was to be passed on to the General Director of Statistics of the Ministry of Agriculture, Industry and Commerce. Lemos argued that the Directorate of Statistics would not be able to carry out the census with its own personnel. He argued that, due to its "special nature", the census of Indians be transferred to the SPI, mentioning initiatives already underway in the Rio Negro and Lower Amazonas and presenting an ethnic-geographic zoning of the area under the jurisdiction of the Inspectorate, scaling the material and personal resources necessary for the census in each zone (BRASIL 1930; 1930a). In practice, the plan (which was not adopted) proposed that the indigenous census be coordinated by SPI Regional Inspectors, assisted by census takers and specific agents. In any case, the bold initiative provides an idea of the horizon of possibilities established by Decree 5484/1928.

The potential new reach of the SPI had not escaped the notice of Amazonian authorities and politicians, at least in the Baixo Madeira where a new level of indigenous resistance to processes of subjection and territorial expropriation had been taking place ever since the Brazil nuts had increased in value. Both reports presented on the Mura and Munduruku in Borba concluded with references to Decree no. 5484/1928. Judge Renato da Matta praised the progressive nature of the four legal categories established for the classification of Indians. ${ }^{29}$ These revealed that legislators had understood "how complex are the relationships between the so-called true forest-dwellers and those who are already in contact with civilization and who, through approximation made by means of donations, are gradually being integrated into the bosom of civilization". The great and dangerous problem was in the "domain of practice", especially when the law left tasks to the SPI inspectors (BRASIL 1931 Vol. I: 278).

The mayor of Borba would also cite the decision of the Superior Court of Justice of Amazonas, which in 1929 published a judgment stating that the process of incorporation of Indians into civilized society was a matter offact, not law. As such, the court dispensed with the attestation of the competent SPI Inspector, adjudging it sufficient, for the application of the common regime of law, that any evidence be produced of an "Aboriginal" belonging to an agricultural center or living in promiscuous contact with civilized people..$^{30}$

However, the practical effect of legislation is neither given nor contained by its formal objective. In this sense, in the case of Amazonas, we must note the importance of Decree 5484 having been proclaimed in a context of social and institutional relations that provided for its immediate instrumentalization by the Inspectorate and by the indigenous peoples, notably those groups established in territories close to the state capital (the Mura and Munduruku particularly). What this meant is that if the new law provided at that time for the exercise of an indigenous citizenship (even if under tutelage), this was because it was nourished by a process of struggles, institutional actions, acquisition of rights, and strategies of resistance that had been developing at least since the promulgation Law no. 941 of 1917. This process included both the bureaucratic-administrative initiatives of the Bento Lemos administration at the head of the Inspectorate (SANTOS 2009), and the confrontations through which various indigenous peoples reacted to the processes of territorial expropriation and domination.

29 Article 2 of the Decree classified Indians into categories defined according to a civilizing perspective: nomadic Indians, uprooted or village Indians, Indians belonging to indigenous settlements, Indians belonging to agricultural centers or who live promiscuously with civilized people.

30 This understanding was signed in reference to a case that dealt with the granting of guardianship of a Wapishana minor to a private individual, in which the Inspectorate obtained a favorable decision because it was considered proven by the records that the indigenous woman was "really not adapted" (to the country's civilization). See Complaint no. 169 (38), in AMAZONAS (1929). 
There were, therefore, already-established paths and experiences that informed (in the regional context) the instrumentalization of the decree. Paths to "statehood (estadania)", to use the term coined by José Murilo de Carvalho (1996). Imperfect paths, considering the incipient network of the federal Indian Inspectorate, built out of the same personalistic connections so characteristic of clientelist networks in the Amazon region. But paths capable of producing strong effects on the regional scene by connecting indigenous actions in the territories to access to administrative instances and channels authorized to intervene in the definition of what is and is not real (BOURDIEU 1989). It is significant in this sense that the exercise of citizenship fueled some of the most powerful images disqualifying the indigenous condition of the Mura and Munduruku and that the dismantling of the SPI throughout the 193os excluded indigenous peoples from important access to State channels and legality.

Received: January 31, 2021

Accepted: August 18, 2021

\section{Bibliography}

AGÊNCIA BRASIL. CPI da Funai finaliza trabalhos e pede o indiciamento de 67 pessoas. Publicado em 30/05/2017. Available at: https://agenciabrasil.ebc.com.br/politica/noticia/2017-05/cpi-da-funai-finalizatrabalhos-e-pede-indiciamento-de-liderancas. Acessed on 08/25/2021.

AMAZONAS, Governo do Estado. 1917. Lei no. 941, de 17 de outubro de 1917. Autoriza o Governador do Estado a conceder, como posses imemoriais havidas por ocupação primária, todas as terras possuídas atualmente por índios selvagens ou semicivilizados.

AMAZONAS, Governo do Estado. 1918. Mensagem lida perante a Assembleia Legislativa na abertura da terceira sessão ordinária da nona legislatura pelo Governador Pedro de Alcântara Bacellar.

AMAZONAS, Governo do Estado. 1920. Mensagem lida perante a Assembléia Legislativa na abertura da 2a Sessão Ordinária da 1oํㅡ Legislatura.

AMAZONAS, Governo do Estado. 1921. Mensagem lida perante a Assembléia Legislativa na abertura da $3^{\text {a }}$ Sessão Ordinária da 10ª Legislatura.

AMAZONAS, Governo do Estado. 1923. Mensagem lida perante a Assembléia Legislativa na abertura da segunda sessão ordinária da décima primeira legislatura.

AMAZONAS, Governo do Estado. 1928. Mensagem do Presidente Efigênio Ferreira de Salles à Assembléia Legislativa na abertura de sua 3 a Sessão Ordinária da $13^{a}$ Legislatura.

AMAZONAS, Governo do Estado. 1929. Mensagem do Presidente Efigênio Ferreira de Salles à Assembléia Legislativa na abertura da $1 \underline{a}$ Sessão Ordinária da 14ํㅡㄹ Legislatura, p. 217.

AMAZONAS. Tribunal de Justiça do Estado do. 1929. Julgados e Decisões - 1929 (20 Semestre). Manaus: Imprensa Pública.

AMAZONAS. Gabinete do Interventor Federal no Estado do Amazonas. 1931. Ato no. 193, de 21 de janeiro de 1931. 
BOURDIEU, Pierre. 1989. "A força do Direito. Elementos para uma sociologia do campo jurídico". O Poder Simbólico. Lisboa: Difel, p. 209-254.

BRASIL. Ministério da Agricultura, Indústria e Comércio. Serviço de Inspetoria e Defesa agrícola. Inspetoria Agrícola do 1을 Distrito. 1913. Questionário sobre as condições da agricultura dos municípios do Estado do Amazonas. Rio de Janeiro: Tipografia do Serviço de Estatística.

BRASIL. Ministério da Agricultura, Indústria e Comércio. Serviço de Proteção aos Índios. Inspetoria no Estado do Amazonas e Acre. 1921. Relatório do Inspetor referente aos trabalhos realizados no exercício de 1920 na Inspetoria do Amazonas e Acre.

BRASIL. Ministério da Agricultura, Indústria e Comércio. Serviço de Proteção aos Índios. Inspetoria no Estado do Amazonas e Acre. 1925a. Ofício no. 588, de 01/07/1925. Do Inspetor Bento Martins Pereira de Lemos, ao Interventor Federal no Amazonas, Alfredo de Sá.

BRASIL. Ministério da Agricultura, Indústria e Comércio. Serviço de Proteção aos Índios. Inspetoria no Estado do Amazonas e Acre. 1925. Report dated 10/25/1925.

BRASIL. Ministério da Agricultura, Indústria e Comércio. Serviço de Proteção aos Índios. Inspetoria no Estado do Amazonas e Acre. 1925. Relatório do Inspetor referente aos trabalhos realizados no exercício de 1924 na Inspetoria do Amazonas e Acre.

BRASIL. Ministério da Agricultura, Indústria e Comércio. Serviço de Proteção aos Índios. Inspetoria no Estado do Amazonas e Acre. 1928. Ofício s/no, de 26/05/1928. De Leônidas Oliveira, auxiliar técnico, para Bento Martins Pereira Lemos, Inspetor.

BRASIL. Ministério da Agricultura, Indústria e Comércio. Serviço de Inspeção e Fomento Agrícola. 1929. A Exploração da Castanha do Pará. Rio de Janeiro: Imprensa Oficial.

BRASIL. Ministério da Agricultura, Indústria e Comércio. Serviço de Proteção aos Índios. Inspetoria no Estado do Amazonas e Acre. 1930. Ofício no. 125/10, dated 02/25/1930.

BRASIL. Tribunal Especial/Procuradoria. 1931. Autos da Comissão de Inquérito na Inspetoria dos Serviços de Proteção aos Índios. Volumes I, II, III e IV. Acervo do Arquivo Nacional, Fundo Tribunal Especial, Série Procuradoria. Notação: No. 640, Vol. I, Depósito 311.

CARVALHO, José Murilo. 1996. “Cidadania: tipos e percursos”. In: Estudos Históricos, Vol. 9, no. 18. Justiça e Cidadania. Rio de Janeiro, CPDOC/FGV.

CARVALHO, José Murilo. 2005. "Mandonismo, Coronelismo e Clientelismo: uma discussão conceitual”. In: Pontos e Bordados: escritos de história e política. Belo Horizonte: Ed. UFMG, p. 130-153.

COELHO, Luís Carlos H. de V. 2004. "O Termo de Bem Viver". In: Revista de Doutrina e Jurisprudência no. 4 - 1o sem. 2004. Manaus: Tribunal de Justiça do Estado do Amazonas.

COSTA, Julia M. D. O "agir temerário, fraudulento e tirânico": a antropologia e os antropólogos segundo a CPI da Funai e do Incra (2015-2017). Masters dissertation in social anthropology. Universidade de Brasília, Brasília, 2019.

COUTINHO, Leonardo; PAULIN, Igor; MEDEIROS, Julia. 2010. "Especial: A farra da antropologia oportunista”. Revista Veja, 05 de maio, 2010, p. 154-161. Available at: https:||pib.socioambiental.org/pt/ Not\% $C_{3} \%$ ADcias?id $=84512$ Accessed on 28/01/2021.

EMMI, Marília. 1987. A oligarquia do Tocantins e o domínio dos castanhais. Belém: Centro de Filosofia e Ciências Humanas/UFPA.

INSTITUTO SOCIOAMBIENTAL. Terras Indígenas e Unidades de Conservação na Amazônia Legal Brasileira - março de 2019. Mapa em formato PDF. Available at: https://acervo.socioambiental.org/acervo/mapas-ecartas-topograficas/amazonia/terras-indigenas-e-unidades-de-conservacao-na-o Accessed on 31/08/2021. 
MELO, Joaquim Rodrigues de. 2007. SPI: A política indigenista no Amazonas. Manaus: Governo do Estado do Amazonas/Secretaria de Estado da Cultura.

PACHECO DE OLIVEIRA, João. 1979. "O Caboclo e o Brabo: Notas sobre duas modalidades de força-detrabalho na expansão da fronteira amazônica no século XIX”. Encontros com a Civilização Brasileira, Rio de Janeiro: Civilização Brasileira, no. 11, p. 101-140.

PACHECO DE OLIVEIRA, João. 1988. "O Nosso Governo". Os Ticuna e o regime tutelar. São Paulo: Marco Zero/ MCT-CNPq.

REIS, Arthur Cezar Ferreira. 1944. O processo histórico da economia amazonense. Rio de Janeiro: Imprensa Nacional.

REIS, Arthur Cezar Ferreira. 1953. O seringal e o seringueiro. Documentário da vida rural, no. 5. Rio de Janeiro: Ministério da Agricultura/Serviço de Informação Agrícola.

REVEL, Jacques. 1998. "Microanálise e construção do social". Jogos de escalas: a experiência da microanálise. Rio de Janeiro: Editora da Fundação Getúlio Vargas, p. 15 a 38.

SANTOS, Ana Flávia Moreira. Conflitos fundiários, territorialização e disputas classificatórias. Autazes (AM), primeiras décadas do séc. XX. Doctoral thesis in social anthropology. Museu Nacional/UFRJ, Rio de Janeiro, 2009.

SANTOS, Ana Flávia Moreira. "Taxonomias Legais e Imagens Étnicas nos Autazes e Baixo Madeira, 19121931". Teoria \& Sociedade (UFMG), v. Especial, p. 219-234, 2014.

SANTOS, Eloína Monteiro. 2001. A Rebelião de 1924 em Manaus. Manaus: Ed. Valler.

SANTOS, Roberto. 1980. História Econômica da Amazônia (180o-1920). São Paulo: T. A. Queiroz.

SOARES, José Carlos de Macedo. 1927. A Borracha. Estudo econômico e Estatístico. Paris: Librarie de Jurisprudance L. Chauny et L. Quinsac.

SOUZA LIMA, Antonio Carlos. 1995. Um grande cerco de paz. Poder tutelar, indianidade e formação do Estado no Brasil. Petrópolis: Vozes.

VIANNA, Adriana de R. B. 1995. "Cartas de Rotina, Cartas de Compromisso: considerações sobre administração e relações pessoais na Primeira República”. In: Antropologia Social, Comunicações do PPGAS, Rio de Janeiro, UFRJ, no. 5, p. 1-20, março 1995.

WEINSTEIN, Barbara. 1993. A borracha na Amazônia: expansão e decadência - 1850-1920. São Paulo: Hucitec/ EDUSP.

ZHOURI, Andréa; LASCHEFSKI, Klemens. 2010. "Desenvolvimento e conflitos ambientais: um novo campo de investigação". In: . (orgs). Desenvolvimento e Conflitos Ambientais. Belo Horizonte: Editora da UFMG, p. 11-31.

Ana Flávia Moreira Santos

Federal University of Minas Gerais, Belo Horizonte/MG, Brazil

https://orcid.org/0000-0002-5331-5079

Email:anafms@ufmg.br 
Annex

People/Roles/Places

\begin{tabular}{|c|c|c|}
\hline Name & Role & Lugar \\
\hline Alcântara Bacelar & Governor of the State of Amazonas, 1917-1920. & Manaus \\
\hline César do Rego Monteiro & Governor of the State of Amazonas, 1921-1924. & Manaus \\
\hline Efigênio Sales & $\begin{array}{l}\text { Governor of the State of Amazonas, 1926- } \\
1929 .\end{array}$ & Manaus \\
\hline Álvaro Maia & $\begin{array}{l}\text { Federal Intervenor in the State of Amazonas } \\
\text { Nov. } 1930 \text {-- July } 1931 .\end{array}$ & Manaus \\
\hline Bento Martins Pereira de Lemos & $\begin{array}{l}\text { Chief Inspector of the } 1^{\text {a }} \text { Inspetoria Regional } \\
\text { do Serviço de Proteção aos Indígenas (State of } \\
\text { Amazonas and Territory of Acre, } 1916 \text {--1932. }\end{array}$ & Manaus \\
\hline José Guimarães & $\begin{array}{l}\text { Manager sent by the Inspectorate to } \\
\text { administrate the nut harvest in the Mura } \\
\text { village of Madeira in 1924. Linked to police } \\
\text { forces. }\end{array}$ & $\begin{array}{l}\text { Mura villages along the } \\
\text { Madeira River. }\end{array}$ \\
\hline Odorico Ferreira Chaves & $\begin{array}{l}\text { Landholder, police officer among the Igapó- } \\
\text { Açu Indians between } 1923 \text { and 1931. }\end{array}$ & Cunhã nut circuit \\
\hline Militino de Souza e Silva & $\begin{array}{l}\text { Munduruku, police officer for the Laranjal } \\
\text { Indians from at least 1925, still in this } \\
\text { position in } 1931 .\end{array}$ & $\begin{array}{l}\text { Laranjal, Laguinho, Paca } \\
\text { Cipó Villages (Canumã- } \\
\text { Abacaxis interfluvial } \\
\text { region). }\end{array}$ \\
\hline José Sant'Anna de Souza & $\begin{array}{l}\text { Responsible party, according to the } \\
\text { Inspectorate, for the Cunhã nut circuits in } \\
\text { 1931. A Civil Policeman on leave. }\end{array}$ & Cunhã nut circuit \\
\hline Augusto Costa & $\begin{array}{l}\text { Colonel, rubber baron, owner of the Vista } \\
\text { Alegre rubber circuits, land speculator in } \\
\text { Mura lands along the Rio Madeira. }\end{array}$ & $\begin{array}{l}\text { Vista Alegre rubber circuit } \\
\text { (Mura villages along the } \\
\text { Madeira River). }\end{array}$ \\
\hline Luís José Soares & $\begin{array}{l}\text { Colonel Augusto Costa's son-in-law, married } \\
\text { to Corina da Costa Duarte. Subprecinct } \\
\text { Commander of Police in } 1925 \text { and Indian } \\
\text { police officer in } 1928 .\end{array}$ & $\begin{array}{l}\text { Vista Alegre rubber circuit } \\
\text { (Mura villages along the } \\
\text { Madeira River). }\end{array}$ \\
\hline Corina da Costa Soares & $\begin{array}{l}\text { Daughter of Augusto Soares and wife of Luís } \\
\text { José Soares. Professor at the Laranjal School } \\
\text { from } 1927 \text { on. }\end{array}$ & $\begin{array}{l}\text { Vista Alegre rubber circuit } \\
\text { (Mura villages along the } \\
\text { Madeira River). }\end{array}$ \\
\hline Raimundo Venâncio da Costa Leite & $\begin{array}{l}\text { Head of the Laranjal Indigenous Post in } 1931 . \\
\text { Nephew of Bento Martins Pereira Lemos }\end{array}$ & $\begin{array}{l}\text { Laranjal Indigenous } \\
\text { Post (Canumã-Abacaxis } \\
\text { interfluvial region) }\end{array}$ \\
\hline Manoel João dos Santos & $\begin{array}{l}\text { Munduruku, Captain of the Indians in } \\
\text { Laranjal, Laguinho, Paca and Cipó villages } \\
\text { in 1931. }\end{array}$ & $\begin{array}{l}\text { Laranjal, Laguinho, Paca } \\
\text { Cipó Villages (Canumã- } \\
\text { Abacaxis interfluvial } \\
\text { region). }\end{array}$ \\
\hline Pessoa Sobrinho & $\begin{array}{l}\text { A family that was part of the rural oligarchy, } \\
\text { with territorial holdings and political control } \\
\text { in Borba during the first decades of the 2oth } \\
\text { Century. Would-be owners of the lands of the } \\
\text { Munduruku villages. }\end{array}$ & $\begin{array}{l}\text { Laranjal, Laguinho, Paca } \\
\text { Cipó Villages (Canumã- } \\
\text { Abacaxis interfluvial } \\
\text { region). }\end{array}$ \\
\hline
\end{tabular}

